\title{
Berbagai Aspek Firasat dalam Cerpen Firasat Karya Dewi Lestari: Sebuah Kajian Paratekstual
}

\author{
Ferdiana \\ Universitas Indraprasta PGRI \\ Jalan Nangka No. 58 C/TB. Simatupang, Tanjung Barat, Jakarta Selatan 12530 \\ wulanferdiana@yahoo.com
}

\begin{abstract}
The aims of this research are 1) to reveal various aspects of hunch as a plot motive in "Firasat" short story, written by Dewi Lestari, 2) to reveal various things concerning hunch in "Firasat" short story by Dewi Lestari. The methodology of research that used is a qualitative method by using a semiotic analysis approach and a paratextualanalysis of "Firasat" song lyrics and short storywritten by Dewi Lestari. The collection of data was done by literature study technique and the data analysis was done by using descriptive techniques, where the researcher describes while analyzing. The result of the research, can be concluded asfollow: 1). The finding of the main themeof hunch and plot, 2) There is a motive as a flow (moving)plot 3) There is a parallel relationship in the theme of the story and song lyrics, and it's called as a hunch of departure on the person they love, 4) There are parallel relationships among the theme, figures and figures who like to hunch.
\end{abstract}

Keywords: hunch aspects, short story

\begin{abstract}
Abstrak
Tujuan dari penelitian ini adalah 1) Mengungkapkan berbagai aspek firasat dalam cerpen "Firasat" karya Dewi Lestari, 2) Mengungkapkan berbagai hal menyangkut firasat dalam cerpen "Firasat" karya Dewi Lestari 3) Mengungkapkan parateks yang mengiringi firasat dalam cerpen "Firasat" karya Dewi Lestari. Metode Penelitian yang digunakan adalah metode kualitatif dengan menggunakan pendekatan analisis semiotika dan kajian paratekstual terhadap lirik lagu dan cerpen "Firasat" karya Dewi Lestari. Sumber data penelitian adalah kumpulan cerpen Rectoverso berjudul "Firasat" karya Dewi Lestari yang diterbitkan pertama kali pada tahun 2008 dan terbitan ketujuh pada tahun 2014 dengan tebal 170 halaman dengan penerbit PT. Bentang Pustaka, Yogyakarta Pengumpulan data dilakukan dengan teknik studi pustaka dan analisis data dilakukan dengan tehnik deskriptif, analisis di mana peneliti menguraikan sambil menganalisis. Hasil penelitian menyimpulkan : 1) Terdapat temuan aspek firasat dalam alur, 2) Terdapat hal yang menyangkut lirik lagu dan cerpen "Firasat" 3) Adanya parateks yang mengiringi cerpen "Firasat".
\end{abstract}

Kata Kunci: aspek firasat, cerpen

\section{PENDAHULUAN}

Pada saat ini kita berada di zaman milenial di semua hal mengalami digitalisasi, buku-buku bacaan dan surat kabar digantikan posisinya oleh $e$-book dan online media. Sementara komunikasi verbal tergantikan oleh tulisan-tulisan singkat di layar alat-alat digital, karya sastra bisa jadi menempati posisi akhir dalam daftar pencarian yang dianggap penting oleh generasi muda saat ini. Televisi, media permainan digital, media belanja online, berbagai jenis media sosial dan alat digital lainnya. 
Dalam situasi seperti ini tentu saja patut disayangkan, karena seperti yang disampaikan oleh Poe dalam Wellek dan Warren (1995), sastra berfungsi menghibur dan sekaligus mengajarkan sesuatu. Ini artinya bahwa sastra tidak hanya dapat dinikmati sebagai media hiburan, tetapi juga berfungsi sebagai media pembelajaran bagi masyarakat. Ketika karya sastra disampaikan dalam bentuk lisan, sastra terbukti merupakan media yang efektif untuk menyampaikan pesanpesan moral dan menyuarakan aspirasi sosial. Dengan sastra kedua hal tersebut dapat disampaikan dengan cara yang indah dan menghibur.

Dengan keberadaannya yang semakin terpinggirkan, dan fungsi yang sesungguhnya teramat penting bagi perkembangan budaya dan moral suatu bangsa, karya sastra membutuhkan inovasi-inovasi yang mampu membuatnya merebut kembali posisinya dalam hati dan pikiran manusia. Inovasi yang dimaksud, bukan hanya berkaitan dengan isi sastra yang harus mengikuti kondisi zaman masyarakat pembacanya, tetapi dalam hal bentuk penyajian yang berbeda dari karya sastra pada umumnya sehingga menarik perhatian calon pembacanya.

Saat ini banyak inovasi yang dapat kita temukan dalam penulisan karya sastra di dunia. Munculnya karya-karya yang dikategorikan sebagai fiksi mini atau flash fiction, misalnya, menjawab kebutuhan pembaca akan karya-karya yang dapat dinikmati di tengah segala kesibukan yang semakin menyita waktu. Ada pula fan fiction yang oleh sebagian pihak belum diakui sebagai karya sastra seutuhnya karena lebih merupakan modifikasi seorang penggemar terhadap karya sastra yang dikaguminya. Ada pula penulis-penulis yang berinovasi dalam bentuk penyajian cerita yang dibuat seolah-olah diambil langsung dari laman sebuah media sosial.

Teeuw (1982) mengungkapkan bahwa sastra umumnya dalam penggunaan bahasa dan penjelmaan bahasa yang khas ini tidak mungkin kita pahami dengan sebaik-baiknya tanpa pengertian, konsepsi bahasa yang tepat. Fungsi sastra dianggap salah satu fungsi bahasa di antara beberapa fungsi yang pernah dirumuskan oleh Roman Jakobson dan Jan Mukarovsky, keduanya ahli bahasa yang terkemuka.

Sastra merupakan sebuah "sekundares modellbildendes system", sekunder tidak hanya dalam arti bahwa sastra memakai bahasa wajar sebagai bahasannya dengan seluruh sistem maknanya dan lain-lain, melainkan pula oleh karena sistem sastra dibangun pula sesuai dengan tipos, macam bahasa. (Teeuw, 1982). Wellek dan Warren (2014) mengungkapkan bahwa sastra adalah suatu kegiatan kreatif, sebuah karya seni. Sastra merupakan seni yang menggunakan bahasa sebagai bahan bakunya. Sastra berfungsi menghibur dan sekaligus mengajarkan sesuatu. Ini artinya bahwa sastra tidak hanya dapat dinikmatisebagai media hiburan, tapi juga berfungsi sebagai media pembelajaran bagi masyarakat.

Wellek dan Warren (2014) mengungkapkan bahwa fungsi sastra adalah dulce (indah/menghibur) dan utile (berguna) tersebut secara luas. Indah/menghibur jika diartikan secara luas bisa berarti tidak membosankan, tidak menimbulkan rasa tertekan atau tidak membuat depresi. Sementara itu berguna dapat diartikan tidak menyia-nyiakan waktu. Dengan menggunakan pengertian secara luas seperti itu, maka fungsi sastra masih dapat dianggap relevan dalam kehidupan sekarang.

Bressler (1999) mempunyai pendapat yang sama dengan Wellek dan Warren menyebut dua fungsi tersebut dengan istilah to teach mengajar dan to

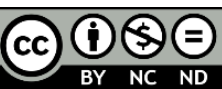

Creative Commons Attribution-NonCommercial-NoDerivatives 4.0 International License 
entertain menghibur. Fungsi menghibur (dulce) artinya sastra memberikan kesenangan tersendiri dalam diri pembaca sehingga pembaca merasa tertarik membaca sastra. Fungsi mengajar (utile) artinya sastra memberikan nasihat dan penanaman etika sehingga pembaca dapat meneladani hal-hal positif dalam karya sastra. Dalam hal ini sastra memampukan manusia menjadi lebih manusia, mengenal diri, sesama, lingkungan dan berbagai permasalahan kehidupan. Alasan mengapa sastra harus memuat sifat dulce el utile, karena itu termasuk ciri khas karya sastra. Walaupun sastra identik dengan nilai keindahan dan nilai manfaat, namun keindahan itu relatif, setiap orang memiliki kriteria yang berbeda-beda dalam penafsirannya. Unsur pesona (dulce) dalam sastra dapat ditemukan hampir dalam semua jenis karya sastra seperti puisi, prosa dan drama.

Sebuah karya sastra yang baik minimal mengandung dua fungsi utama tadi. Artinya, sebuah karya sastra dapat dikatakan bernilai sastra tinggi supaya karya itu mampu memberikan hiburan kepada pembaca, serta mampu memberikan pengajaran positif bagi pembacanya. Karya sastra yang hanya mampu memberikan hiburan tanpa ada manfaat akan terasa gersang. Demikian pula karya sastra yang hanya mampu memberikan manfaat dan tidak mampu memberikan hiburan bagi pembaca akan terasa hambar. Oleh sebab itu sastra dapat dikatakan merupakan media mengajar dan media pengajaran.

Pemilihan cerpen "Firasat" sebagai objek penelitian didasarkan pada alasan bahwa cerpen "Firasat" termasuk cerpen ketujuh yang di dalamnya terdapat parateks dan sebuah lirik lagu yang ditulis sendiri oleh Dee yang merupakan seorang artis penyanyi, penulis lagu dan karya sastra. Dikisahkan oleh Dee bahwa ia terlebih dahulu menuliskan kesebelas lagu dalam buku Rectoverso, yang di dalamnya termasuk cerpen "Firasat" kemudian menuliskan sebuah cerita pendek untuk masing-masing lagu yang telah diciptakannya. Ini merupakan sesuatu yang di luar kebiasaan, dan merupakan sesuatu yang inovatif, karena yang sering terjadi adalah penulis membuat karya sastra (baik cerpen, novel maupun puisi) terlebih dahulu kemudian di wujudkan ke dalam bentuk karya yang lebih mudah dinikmati masyarakat secara luas, seperti film, lagu, atau pentas drama. Kombinasi talenta yang demikian sangat jarang ditemukan di Indonesia.

\section{METODE}

Penelitian ini merupakan penelitian tekstual dengan karya sastra sebagai objek kajiannya. Berdasarkan hal tersebut di atas, penelitian ini bersifat dinamis dan tidak terikat oleh ruang dan waktu sehingga dapat dilakukan dimana saja. Dan penelitian ini termasuk ke dalam penelitian kebahasaan, maka tidak ada bahasan khusus terhadap tempat dan waktu, dan dapat dilakukan di perpustakaan dimana saja tidak tergantung pada tempat, karena instrument penelitian yang digunakan berkaitan dengan analisis isi yaitu membaca cerpen "Firasat" karya Dewi Lestari.

Penelitian ini merupakan penelitian kualitatif. Pendekatan kualitatif digunakan untuk metode penelitian ilmu-ilmu humaniora pada umumnya, dan ilmu sastra pada khususnya, yang objeknya adalah teks. Metodologi kualitatif dijelaskan oleh Bogdan dan Taylor dalam Moleong (2001) sebagai prosedur penelitian yang 
menghasilkan data-data deskriptif berupa kata-kata tertulis atau lisan dari orangorang dan perilaku yang dapat diamati. Oleh karena itu, data yang dikumpulkan adalah data yang berupa kata atau kalimat maupun gambar (bukan angka-angka). Data-data tersebut bisa berupa naskah, wawancara, catatan lapangan, foto, video, dokumen pribadi, memo ataupun dokumen resmi lainnya. Penelitian ini merupakan penelitian yang mengkaji teks dengan menggunakan metode semiotika, yaitu ilmu tentang tanda, yang tercakup dalam metode untuk penelitian kualitatif.

\section{HASIL DAN PEMBAHASAN}

Penelitian ini bermaksud membahas berbagai aspek menyangkut firasat dan hubungan paratekstual antara cerpen "Firasat" sebagai teks inti dengan lirik lagu "Firasat" yang merupakan salah satu parateksnya. Pertama-tama yang akan dikaji adalah tiga aspek semiotik cerpen, yaitu kajian mengenai firasat dalam cerpen "Firasat", sampul buku dan pembahasan alur dan tokoh yang berkaitan dengan ruang dan waktu dalam lirik lagu dan cerpen "Firasat", kedua pembahasan berbagai aspek hubungan firasat pada lirik lagu dan cerpen "Firasat". Ketiga pembahasan parateks yang mengiringi firasat dalam cerpen "Firasat".

\section{Kajian Mengenai Firasat dalam Cerpen "Firasat"}

Dalam hal firasat, banyak hal yang bisa dikategorikan sebagai parateks. Judul buku yang memuatnya bersama sepuluh pasang cerpen dan lirik lagu yang mengiringi, misalnya, merupakan parateks yang wajib untuk dianalisis. Point-point yang akan dibahas dalam sub bab ini, yaitu gambaran catatan pengarang dalam sampul buku, lirik lagu, parateks yang mengiringi cerpen "Firasat" dan catatan Dee.

\section{Sampul Buku Rectoverso Karya Dee}

Sampul buku Rectverso yang terbit tahun 2008 sarat dengan simbol-simbol yang mewakili isi buku. Gambar siluet sederhana sepasang manusia misalnya, selain seolah menyiratkan bahwa buku ini banyak mengusung tema hubungan manusia dan terutama tema cinta di antara sepasang manusia, juga terlihat seperti angka 11 yang merupakan jumlah cerita yang hadir di dalamnya. Angka 11 itu sendiri, seperti yang dijelaskan oleh Dee dalam kata pengantar, adalah bukan sebuah kebetulan. Menurut Dee, ia menyukai angka 11 karena angka ini "dikenal sebagai angka yang mewakili kehadiran alam spiritual yang bersandingan dengan alam material" (Dee, 2008).

Dalam hal buku ini angka sebelas seolah menjadi simbol hubungan setiap cerpen dengan lirik lagu yang paralel, yang mendahuluinya sebagai parateks. Setiap cerpen dalam buku itu didahului oleh sebuah lirik lagu yang sesuai dengan pernyataan Dee dan merupakan petunjuk untuk membaca cerpen tersebut.

\section{Analisis terhadap Lirik Lagu Firasat}

Dalam sub bab ini, penulis akan membahas mengenai sampul buku, analisis terhadap lirik lagu, alur dan penokohan dalam lirik lagu cerpen "Firasat" karya Dee. Lirik dapat disejajarkan dengan puisi, dan seringkali diangkat dari puisi. Keduanya merupakan bentuk karya sastra dengan penggunaan kalimat atau kata. 
Dari hasil unsur-unsur satuan isi puisi lirik lagu cerpen "Firasat" dapat disimpulkan bahwa di dalam puisi tersebut terdapat 12 unsur satuan isi, yang terus dibahas oleh Dee, terlihat banyaknya kalimat perintah langsung mengenai firasat "aku" yang akan terjadi pada orang yang dicintainya. Penggunaan alam sebagai penemuan implisit kadang-kadang bisa menjadi kenyataan.

Dalam hal pembaitan, lirik lagu "Firasat" dituliskan dengan struktur yang sedikit berbeda dari puisi pada umumnya. Lirik lagu ini memang dituliskan dalam bentuk rangkaian bait-bait seperti layaknya puisi, namun jumlah lirik pada setiap bait tidak sama. Bait pertama terdiri dari tujuh larik, tapi beberapa bait lainnya masing-masing terdiri dari lima atau sembilan larik, sementara bait ke lima terdiri dari tiga larik dan ketujuh hanya dua larik. Ketujuh bait "Firasat" tidak sama panjangnya; Bait pertama terdiri dari tujuh larik, Bait kerdua terdiri dari lima larik, bait ketiga terdiri sembilan larik. bait keempat terdiri dari lima larik, bait kelima terdiri dari tiga larik, bait keenam terdiri dari lima larik yang merupakan pengulangan dari bait keempat dan bait ketujuh atau yang terakhit terdiri dari dua larik. Walaupun jumlah larik dalam setiap bait tidak megikuti aturan penulisan puisi pada umumnya, tidak demikian jumlah suku kata dalam setiap lariknya. Jumlah suku kata pada larik lirik lagu firasat dalam cerpen "Firasat" ada dua puluh lima suku kata.

Dari uraian di atas, dapat dianalisis bahwa makna lirik lagu dan puisi "Firasat" menggambarkan firasat yang diterima oleh "aku" yang tidak dapat dihindari. "Aku" mendapatkan dan membaca "firasat" dari peristiwa-peristiwa alam yang dilihat dan dirasakan "Aku". "Aku" berfirasat kehilangan kekasihnya dan firasat itu ternyata benar terjadi.

Lirik lagu "Firasat" bercerita tentang dua tokoh yang diwakili oleh kata "Ku" dan "Mu" (selanjutnya akan disebut sebagai "aku") dan "mu"/'kau" (selanjutnya akan disebut sebagai "kau"). Karakter yang menjadi narator dalam lagu ini adalah "Aku". Kata-kata dalam lagu ini ditujukan "aku" pada "kau" serta banyak menggambarkan "ku" dari kacamata "aku"; "ku" tidak mempunyai suara untuk menggambarkan dirinya sendiri.

Lirik lagu "Firasat" merupakan lagu yang bersifat naratif, baik alur dan karakter tokohnya dapat diuraikan dengan cara yang sama seperti menguraikan suatu cerpen atau novel. Setelah meneliti alur lirik lagu firasat dalam cerpen "Firasat", dapat dianalisis bahwa ada 6 sekuen yang berada pada saat penceritaan dan dapat dijelaskan melalui bagan tersebut di atas. Dari bagan di atas dapat disimpilkan bahwa tidak ada timbal balik antara aku dan firasat yang aku alami dapat dilihat peristiwa-peristiwa yang terjadi dalam membentuk satu kesatuan dan dapat ditarik kesimpulan, yaitu ada jenis motif penggerak yang mempunyai peran besar dan ditimbulkan oleh firasat "aku", sehingga motif kecemasan, ketakutan dan kesedihan akan kehilangan orang yang dicintainya pergi dan tidak akan kembali untuk selama-lamanya, sehingga "aku" tidak bisa melakukan apa-apa mengenai firasat yang datang pada dirinya dengan cara mengikhlaskan dan rela melepaskan kepergiannya. Hal ini menunjukkan alur cerita yang bergerak maju dan peristiwa yang terjadi pada firasat akan benar-benar terjadi dalam waktu yang cepat.

Dalam sebuah cerpen, tokoh-tokoh adalah unsur yang membangun dalam rangkaian cerita. Tokoh "aku" dalam lirik lagu firasat adalah tokoh inti atau tokoh 
utama yang terdapat dalam lirik lagu firasat. Tokoh "aku" menggambarkan seseorang yang mempunyai firasat kuat dan kekhawatiran akan kehilangan "kau", namun "aku" tidak bisa menghindari kejadian yang akan menimpa "kau". Kesedihan akan kehilangan "kau" membuat "aku" menyadarkan "aku" bahwa yang akan pergi tidak akan kembali.

\section{Analisis Cerpen "Firasat"}

Dalam penelitian ini, penulis memilih cerpen "Firasat" karya Dewi Lestari sebagai objek penelitan dengan mempertimbangkan beberapa hal yaitu penulis akan membahas mengenai aspek firasat dan kajian parateks yang teradapat pada cerpen "Firasat".

\section{Analisis Alur}

Untuk menganalisis alur cerpen "Firasat" karya Dewi Lestari, penulis menggunakan teori yang dikemukan oleh Tzvetan Todorov dan Greimas berupa aspek sintaksis dan semantik yang akan mengungkapkan penyajian teks inti berikut ini:

Analisis alur yang digunakan pada cerpen "Firasat" adalah alur maju, dimulai dengan pembuatan satuan isi cerita atau disebut juga dengan urutan satuan teks atau sekuen dan uraiannya dalam cerpen "Firasat" jarya Dewi Lestari. Berikut tahapan-tahapan yang dilakukan dalam analisis alur cerpen "Firasat" adalah sebagai berikut :

\section{Pembahasan Satuan Isi Cerita Cerpen "Firasat"}

Dalam cerpen "Firasat" terdapat 28 sekuen yang penulis buat dalam penceritaan. Untuk analisis tokoh pada sekuen cerpen "Firasat" yang akan dibahas adalah tokoh "aku", Ibu dan Ia yang merupakan tokoh utama yang langsung muncul di awal cerita. Mereka adalah tokoh yang terlibat langsung di dalam cerpen "Firasat".

Tokoh "aku" dapat dianalisis sebagai tokoh yang mempunyai sifat egois dalam mengikuti klub firasat. Setelah mendapat firasat, "aku" merasakan keresahan dan kekhawatiran (seperti terlihat pada sekuen nomor 15). Begitu kuat firasat "aku" akan terjadi sesuatu pada "kau", "aku" tidak dapat menghindari kejadian yang terjadi pada "kau".

Tokoh Ibu adalah orangtua dari "aku", yang dapat dianalisis sebagai tokoh mempunyai rasa sabar dan sangat menyayangi "aku" sebagai anaknya, yang selalu memberikan motivasi dan semangat untuk "aku". Ibu mempunyai tenaga yang kuat dan sanggup menopang badan "aku" pada saat kondisi "aku" mengalami kesedihan akan kehilangan diri "kau", (seperti pada sekuen nomor 24).

Tokoh ia dapat dianalisis sebagai tokoh yang merupakan pimpinan dalam sebuah klub yang bernama klub firasat (seperti terlihat dalam sekuen nomor 2), yaitu seorang pemimpin klub firasat orang yang masih muda dan seumuran dengan "aku", memiliki firasat yang sangat tajam dan berbeda dengan anggota lainnya. Ia mempunyai indra keenam yang merupakan indra yang berperan sebagai indra untuk menangkap informasi tentang dunia sekitar yang tidak bisa diperoleh dengan indra biasa, indra yang bisa merasakan dunia halus, indra yang mempunyai kelebihan dan kemampuan untuk melihat sesuatu yang akan datang terjadi pada orang yang terdekat kita dan memprediksi masa depan. Pesan yang datang pada indra keenam 
biasanya langsung melalui mimpi dan bukan tanpa alasan.

Alur tersebut dapat di analisis bahwa mata ketiga yang dimaksud dalam cerpen "Firasat' adalah mata batin yang dapat merasakan aura yang menyelimuti sekujur tubuh manusia dan hanya orang-orang tertentu yang memiliki mata ketiga. Ari-ari dua lapis yang dimaksud adalah ari-ari atau plasenta pada waktu bayi dilahirkan terbungkus ari-arinya biasanya bayi normal di bungkus dengan satu lapisan, tetapi untuk yang mempunyai kelebihan dibungkus dengan dua lapisan.

Pertemuan aku dan pimpinan klub pada suatu perkumpulan yang bernama klub firasat. Mereka bertemu setiap seminggu sekali dimulai pada pukul tujuh malam. Lokasi pertemuan mereka berpindah-pindah, tapi model pertemuannya tetap sama, yang hadir dua puluhan orang berkumpul membentuk lingkaran, kadang duduk di kursi kadang lesehan. Dalam dua jam pertemuan hanya sebagian anggota yang memilih untuk berbagi. Sisanya hanya mendengarkan dan menanggapi sedikit. Pengertian klub firasat dalam cerpen "Firasat", seperti dalam sekuen nomor 4 gambaran tentang klub firasat:

Sebuah klub yang menjadi wadah bagi mereka yang mempunyai kepekaan indra keenam dan kerap memiliki firasat atas apa yang akan terjadi. Konflik terjadi ketika firasat itu adalah diri kita sendiri dan orang yang paling kita cintai.

Pada pertemuan klub ke-52 aku dan pimpinan klub membahas mengenai rencana perayaan tersebut. Pimpinan klub mengatakan seperti dalam sekuen nomor 13 :

Dari pernyataan yang disampaikan pimpinan klub perkiraan ia tidak akan hadir dalam perayaan tersebut, aku panik dan aku merasakan sesuatu akan terjadi padanya. Di sini aku sudah mulai merasakan firasat akan kepergiannya.

Setelah pertemuan itu, susana hati dan perasaan aku gelisah dan tubuh aku seperti berada di dunia lain. Aku merasakan sesuatu yang tidak seperti biasanya, seperti dalam sekuen nomor 19 :

Pernyataan di atas memperlihatkan firasat yang aku rasakan dan rasa takut akan kehilangan pimpinan klub, orang yang dicintainya. Gejala alam pun memperlihatkan sesuatu yang akan terjadi. Aku berharap ia tidak pergi dan meninggalkannya.

Keadaan akhir aku setelah ia pergi untuk selama-lamanya dan tidak akan kembali. Aku berusaha melepaskan ia dengan perasaan sedih. Seperti terlihat pada sekuen nomor 25 :

Dari uraian di atas dapat dianalisis bahwa firasat pada saat penceritaan adalah sebuah perkumpulan yang bernama klub firasat. Pengetahuan tentang firasat ada pada dunia yang mempuyai ruang dan membahasa mengenai firasat. Tokohtokoh yang berada pada cerpen "Firasat" tidak semua orang mempunyai firasat, hanya tokoh yang memiliki indra keenam yang dapat melihat dan membaca firasat seperti tokoh"aku" dan pimpinan klub. Dari ruang ternyata ada klub dan cara mendapatkan firasat, dengan melihat peristiwa-peristiwa alam yang menandakan sebagai firasat.

Firasat yang datang baik itu firasat yang baik maupun firasat buruk, kita harus berusaha menerima dan melepaskan yang sudah menjadi ketentuan Yang Maha Kuasa. Yang menjadi motif penggerak firasat adalah motif kecemasan, ketakutan dan kehilangan orang yang kita cintai sehingga firasat itu bisa 
menandakan bahwa yang akan pergi tidak akan kembali, hikmah dari setiap kejadian harus mengikhlaskan apa yang sudah menjadi takdirnya.

Sehingga akhir dari semua firasat menjadi kenyataan, dan firasat timbul pada orang yang gemar berfirasat dan ruang yang menjadi tempat perkumpulan orang berfirasat ternyata ada klub yang memfasilitasi orang-orang yang memiliki firasat. Hal ini menunjukkan alur cerita yang bergerak maju dan peristiwa yang terjadi sangat cepat.

\section{Analisis Tokoh dan penokohan dalam Cerpen "Firasat" Karya Dewi Lestari}

Di dalam sebuah cerpen, tokoh-tokoh merupakan unsur yang membangun dalam rangkaian cerita. Pada umumunya tokoh dibedakan menjadi tokoh utama dan tokoh pendukung serta tokoh yang berwatak baik (protagonis) dan tokoh yang berwatak jahat (antagonis). Namun di dalam membaca cerpen "Firasat" karya Dewi Lestari, tidak banyak tokoh-tokoh yang muncul, hanya ada enam tokoh yang terdapat dalam cerpen "Firasat." Nama tokoh hanya disebut aku, ibu (orangtua "aku"), ia, ibu dan bapak (tetangga "ia") kecuali nama anjing disebut bernama anjing bridil. Karakter tokoh-tokoh pada cerpen "Firasat" tidak diketahui dengan jelas pembagiannya. Hanya tokoh "aku" yang mempunyai sifat egois dalam mengikuti perkumpulan klub firasat. Berikut ini uraian tokoh-tokoh dalam cerpen "Firasat" sebagai berikut :

1) $\mathrm{Aku}$

Tokoh "aku" di dalam cerpen "Firasat" adalah seorang perempuan muda yang mempunyai kelebihan kemampuan untuk mengetahui suatu firasat yang kuat apabila akan terjadi pada orang yang dicintainya. "Aku" mempunyai masalah kejiwaan jika sesuatu akan terjadi pada orang terdekatku. Di dalam cerpen "Firasat", "aku" berperan sebagai penutur. "Aku" salah satu anggota klub firasat yang rajin dan tidak pernah satu kali pun pernah absen. Sejak pertama mengikuti perkumpulan klub firasat dan berjumpa dengan pimpinan klub firasat, "aku" merasa akan jatuh cinta pada "kau". "Aku" mempunyai sifat yang egois. "Aku" paham betul tujuanku di tempat itu. Untuk apa, untuk siapa dan supaya apa.

Dari uraian di atas dapat dianalis bahwa nama dan usia pada tokoh "aku" tidak disebutkan, hampir tidak ada gambaran secara fisik, misalnya wajahnya cantik, rambutnya panjang dan sebagainya. Tidak semua orang mempunyai firasat hanya "aku" dan orang yang mempunyai indra keenam yang dapat berfirasat.

2) $\mathrm{Ibu}$

Ibu orangtua dari "aku" yang belum terlalu tua digambarkan dalam cerpen "Firasat" sangat baik dan berusaha mengerti anaknya. Ibu senang mengisi TTS diwaktu luangnya. Ibu sangat paham tentang perubahan yang terjadi pada anaknya dan selalu ada buat "aku". Ibu yang selalu membujuk"aku" untuk tenang dan melepaskan apa yang menjadi beban "aku". Kondisi fisik tidak digambarkan ibu seperti apa, hanya ibu mempunyai tenaga yang kuat untuk menopang tubuh anaknya

Dari uraian di atas dapat dianalisis bahwa usia dan fisik Ibu tidak digambarkan secara detail, hanya menggambarkan ibu yang selalu ada dan 
menjaga "aku" anak dalam keadaan apapun.

3) Ia

Seorang pencetus klub firasat sekaligus pimpinan klub firasat yang masih muda, seumur "aku", semua orang menaruh rasa hormat sekaligus segan.

Dari uraian di atas dapat dianalisis bahwa ia adalah seorang lak-laki muda yang seusia dengan "aku", seorang pimpinan klub yang bernama firasat yang tidak disebutkan usia dan fisiknya seperti apa. Ia adalah pemuda yang dianugerahi firasat yang sangat tajam.

4) Bapak-Ibu

Bapak-Ibu adalah tetangga "kau", sepasang suami-istri manula yang memelihara banyak sekali ayam kate. Sang bapak adalah seorang pensiunan militer dan sang ibu berjualan nasi gudeg. Mereka saling menyayangi dan saling mengurus seperti orang tua dan anak kandung.

Bapak seorang pensiunan militer yang merupakan seorang prajurit negara yang bertugas menjaga keamanan bangsa dan Negara. Ibu hanya seorang ibu rumah tangga dengan menambah kesibukannya dengan berjualan gudeg di rumahnya.

Dari uraian di atas dapat dianalisis bahwa Bapak dan Ibu adalah seorang kakek-kakek dan nenek-nenek yang tidak disebut usianya berapa, dengan kondisi fisik yang tidak disebutkan. Bapak-Ibu seorang yang baik hati sehingga "ia" sudah dianggap seperti anak sendiri.

5) Anjing Brindil

Seekor anjing yang dipelihara oleh pimpinan klub yang suka sekali dengan sup tulang.

Berdasarkan data-data di atas, dapat diperoleh informasi bahwa, cerpen "Firasat" memperlihatkan tokoh utama "aku" yang dalam penokohan memiliki firasat yang kuat dalam berfirasat.

\section{Ruang}

Wadah atau ruang yang digunakan untuk pertemuan dalam klub firasat orang-orang yang sama pintar, ingin berbagi mengenai firasat masing-masing. Apakah firasat yang mempunyai kecenderungan peristiwa buruk atau peristiwa baik. Ruang di sini tidak disebut lokasi atau tempat. Ruang yang dimaksud dalam kutipan di atas tidak di sebutkan rumah atau aula karena lokasi pertemuan mereka berpindah-pindah, tapi modalnya tetap sama. Klub firasat terdiri dari dua puluhan orang berkumpul membentuk lingkaran, kadang dduk di kursi belakang, lesehan, lalu satu orang bercerita dan yang lain mendengarkan. Dalam dua jam pertemuan mungkin hanya tujuh orang yang memilih berbagi,sisanya mendengarkan atau menanggapi. Dengan demikian dapat dianalisis untuk ruang perkumpulan firasat menggunakan tempat atau rumah pimpinan atau anggota yang bersedia ketempatan untuk pertemuan klub firasat tersebut. Jadi setiap minggu pertemuan itu berpindahpindah tempatnya.

Klub yang memfasilitasi orang-orang untuk menghidupkan kembali kemampuannya dan berbagi pengalaman soal firasat masing-masing sehingga bisa membantu orang lain. Klub firasat yang mempertemukan aku dengan pimpinan klub sehingga aku merasakan jatuh cinta sejak pertama kali. 
Setelah meneliti alur cerpen "Firasat", dapat dianalisis mengenai hubungan antar tokoh dan ruang penulis dapat mengambil simpulan mengenai "aku" dan ia, yang dekat dengan alam dan bisa membaca peristiwa-peristiwa alam sebagai sumber firasatnya.

\section{Berbagai Aspek Hubungan Firasat Pada Lirik Lagu dan Cerpen "Firasat"}

Telah dijelaskan sebelumnya bahwa "Firasat" adalah satu kesatuan yang terdiri dari sebuah lagu dan sebuah cerpen. Keduanya merupakan bagian dari kumpulan cerpen Rectoverso karyaDewi Lestari. Menurut penuturan Dee, ia terlebih dahulu menuliskan kesebelas lagu yang terdapat di dalam kumpulan cerpen Rectoverso, lalu menuliskan cerita pendek yang menjadi pasangan setiap lagu. Dengan fakta ini saja, seharusnya bisa ditarik kesimpulan bahwa keduanya erat berhubungan. Namun bagaimana hubungan keduanya, apakah terdapat kesamaan maupun perbedaan diantara keduanya. Bagian ini akan berisi pembahasan mengenai hal-hal tersebut.

\section{Aspek Alur}

Yang dimaksud dengan alur adalah tahapan-tahapan peristiwa yang dirangkai sedemikian rupa oleh pengarang hingga membentuk suatu cerita. Jika mengamati bagan sekuen lagu dan cerpen yang sudah dijelaskan pada bagian sebelumnya, alur keduanya tidak jauh berbeda. Aspek alur pada lirik lagu "Firasat" dan cerpen "Firasat mempunyai satu kesamaan yang dapat terlihat pada sekuen lirik lagu nomor 8 dan sekuen pada cerpen nomor 18, sekuan lirik lagu nomor 13 dan sekuen pada cerpen nomor 25 , sekuan lirik lagu nomor $6 \& 7$ dan sekuen pada cerpen no 27.

Dari uraian di atas dapat dianalisis bahwa alur pada lirik lagu dan cerpen "Firasat" mempunyai kesamaan yaitu sama-sama membahas firasat, ruang yang ditampilkan keduanya melalui peristiwa-peristiwa alam yang menjadi firasatnya.

\section{Aspek Tema}

Dilihat dari pola interaksi antar tokoh dalam lirik lagu maupun dalam cerpen "Firasat", ditemukan bahwa, Firasat dibangun di atas tema yang sama, yaitu firasat akan kehilangan orang yang dicintai "aku".

Dari uraian di atas dapat dianalisis bahwa kedua tokoh utama dalam lagu dan cerpen "Firasat" sama-sama mencintai seseorang "Aku" mencintai "Mu". Kesamaan lainnya adalah bahwa keduanya mendapat firasat kesedihan dan kekhawatiran akan terjadi sesuatu dan kehilangan orang yang dicintai yang akan pergi dan tak akan kembali dan yang menjadi motif penggeraknya adalah firasat.

\section{Aspek Latar}

Latar suasana adalah salah satu bagian dari suatu karya sastra, terutama karya yang berupa narasi. Susana yang mendominasi sebuah teks narasi dihadirkan melalui pilihan kata yang banyak digunakan dalam suatu teks narasi, dan juga melalui cara penceritaan.

Dalam lirik lagu "Firasat", suasana yang terbaca adalah suasana sedih yang digambarkan dengan rasa jangan pergi lagi. Tokoh "aku" mempunyai firasat sedih dapat terbaca pada lirik nomor 35 . 
Dalam lirik lagu ini "aku” mengutarakan kesedihan tentang firasat aku yang menginginkan "kau" tidak pergi dan meninggalkannya.

Suasana sedih juga terasa dalam cerpen "Firasat". Berbeda dengan lirik lagu, suasana sedih lebih banyak dihadirkan oleh Aku mengenai firasat akan kehilangan pimpinan klub,

Susana sedih ini memuncak setelah kepergian orang yang dicintainya. Penulis menggambarkan kesedihan yang mendalam karena kehilangan sosok orang yang dicintai oleh "Aku"..

Dari uraian latar lirik lagu dan cerpen firasat dalam cerpen "Firasat" dapat dianalisis bahwa kedua latar mempunyai kesamaan yaitu kekhawatiran dan kesedihan akan kepergian orang yang dicintai "aku".

\section{Parateks yang Mengiringi Firasat dalam Cerpen "Firasat Karya Dewi Lestari}

Lirik lagu firasat adalah parateks yang mengiringi cerpen "Firasat" dan firasat merupakan teks inti dalam cerpen "Firasat". Hasil analisis yang dapat diperolah dengan mengacu pada temuan peneliti dan deskripsi di atas, pada tataran sintaktik, semantik dan pragmatik yang ditemukan dalam cerpen "Firasat" karya Dewi Lestari. Berdasarkan data-data di atas dapat disimpulkan bahwa pengaluran dalam lirik lagu dan cerpen "Firasat" karya Dewi Lestari yang meliputi peristiwa peristiwa alam dan merupakan penggambaran motif penggerak dalam berfirasat. Tokoh "aku" yang memiliki firasat buruk tidak dapat menghindari firasat itu. Kekhawatiran dan kesedihan yang akan pergi dan tak akan kembali.

Selain itu terdapat dua tokoh yang terdapat dalam lirik lagu dan lima tokoh yang terdapat pada cerpen "Firasat" karya Dewi Lestari.Tokoh "aku" sebagai tokoh utama yang terdapat dalam lirik lagu dan cerpen "Firasat" merupakan cerminan adanya unsur-unsur penokohan dan nilai-nilai kejiwaan tokoh "aku" yang terlibat dalam cerpen tersebut. Dalam mengkaji unsur penokohan dalam lirik lagu dan cerpen "Firasat", penulis melihat sudut pandang pengarang yang berfungsi sebagai tokoh utama atau bisa disebut dengan dengan sudut pandang orang pertama. Keberadaan pengarang sebagai orang pertama menyebabkan penulis lebih berfokus pada penelitian ini dalam konteks penokohan. Penokohan dalam lirik lagu dan cerpen "Firasat" karya Dewi Lestari merupakan perilaku tokoh yang memiliki indra keenam dan mempunyai firasat yang kuat dalam berfirasat.

Berdasarkan uraian di atas analisis penokohan dalam lirik lagu dan cepen "Firasat" karya Dewi Lestari menggunakan penokohan analtik. Tokoh "aku" berwatak egois, tokoh anggota klub firasat dan orangtua yang mencerminkan penokohan dramatik dan lebih mirip dengan yang ditampilkan pada drama, dilakukan secara tak langsung artinya pengarang melalui perantara tokoh yang satu menggambarkan tokoh lainnya.

Latar/setting dalam lirik lagu dan cerpen "Firasat" karya Dewi Lestari, jika kita membacanya hanya menggambarkan tempat perkumpulan klub firasat, rumah dan peristiwa alam, yang dari awal sampai akhir cerita didominasi oleh diskusi antar tokoh dan tokoh "aku" yang berfirasat buruk 


\section{SIMPULAN}

Berdasarkan hasil dan pembahasan, dapat disimpulkan bahwa: 1) Terdapat temuan aspek firasat dalam alur. 2) Terdapat hal yang menyangkut lirik lagu dan cerpen "Firasat". 3) Adanya parateks yang mengiringi cerpen "Firasat".

\section{DAFTAR PUSTAKA}

Bressler (1999). Literary Criticism. United State of America; Prentice-Hall International. UK, London

Dee. (2014), Rectoverso. Yogyakarta: Bentang Pustaka

Moleong, L.J. (2005). Metodologi Penelitian Kualitatif. Bandung: Rosdakarya.

Teeuw, A. (1982). Membaca dan Menilai Sastra. Jakarta: Gramedia Pustaka Utama.

Wellek, R. \& Warren, A. (1995). Teori Kesusastraan. Diindonesiakan oleh Melani Budianta. Jakarta: Gramedia Pustaka Utama.

Wellek, R. \& Warren, A. (2014). Teori Kesusastraan. Diindonesiakan oleh Melani Budianta. Jakarta: Gramedia Pustaka Utama. 